М.Д. Чемич, А.О. Горбачевський

\title{
КЛІНІКО-ЛАБОРАТОРНІ ОСОБЛИВОСТІ ЦИРОЗУ ПЕЧІНКИ, АСОЦІЙОВАНОГО З ВІРУСАМИ ГЕПАТИТІВ
}

\author{
Сумський державний університет
}

HCV-інфрекція є однією з основних причин хронічних захворювань печінки у всьому світі, цироз - небезпечне ускладнення хронічних захворювань печінки, підсумовує ряд прогресуючих етапів. На початку захворювання хвороба перебігає латентно і проявляється неспецифрічними ознаками, аж до маніфестації значних порушень фрункцій печінки.

мета роботи - дослідити клініко-лабораторні особливості цирозу печінки, асоційованого з вірусами гепатитів.

Матеріали і методи. Проаналізовано медичні карти стаціонарних хворих та обстежено 107 пацієнтів віком $(47,1 \pm 12,1)$ року, які отримували лікування у КНП СОР «Медичний клінічний чентр інфекційних хвороб та дерматології імені 3. Красовицького» та Сумській обласній клінічній лікарні у 2015-2019 рр. Хворі були поділені на 2 групи - цироз, асоційований з вірусами гепатитів (I-a) та цироз невірусного походження (II-а). Клінічні дані та біохімічні показники крові зіставляли з групою порівняння, яку склали 70 здорових осіб віком $(45,6 \pm 2,1)$ року. Дані дослідження були опрацьовані методом варіаційної статистики.

Результати. При вірусному цирозі переважають мешканці міста, чоловіки середнього віку з надмірною масою тіла. Незважаючи на переважання мінімальної активності цирозу класу А і В (за Чайлд-П'ю), неінвазивні тести вказували на більшу кількість пацієнтів зі значнішим фріброзом при цій недузі. Найчастіше ймовірним шляхом зараження є медичні маніпуляції і вживання ін'єкційних наркотиків. При цьому домінують астеновегетативний синдром, тяжкість у правому підребер'ї, субіктеричність склер, спленомегалія, енцефралопатія, серед супутніх захворювань - холецистит, метаболічна кардіоміопатія. Недуга супроводжується тромбоцитопенією, прискоренням ШОЕ, білірубінемією та трансфераземією, збільшенням ехогенності печінки і розширенням розміру селезінкової вени.

Висновок. Цироз, асоційований з вірусами гепатитів має тяжчий перебіг, яскраву клініко-лабораторну симптоматику з переважанням фріброзоутворення, потребує комплексного обстеження та постійного спостереження.

Ключові слова: HCV-інфрекція, цироз, фрібротест, УЗД печінки.

Цироз - це дифузний процес, який характеризується заміщенням паренхіми печінки аномально організованими вузлами сполучної тканини, розділеними фріброзними перегородками. Найпоширенішими причинами цирозу є вірус гепатиту C (HCV) та надмірне вживання алкоголю, але останнім часом значну роль у розвитку цього стану відіграють неалкогольні жирові захворювання печінки. Хвороба надзвичайно неоднорідна та динамічна і може бути диференційована на різні стадії, кожна з яких має певні унікальні характеристики [1]. У світі інфріковано HCV близько 150 млн людей. Це одна 3 головних причин захворюваності та смертності, пов'язаних з ураженням печінки та розвитком фріброзу, цирозу, ускладнень від невчасно виявлених і пролікованих випадків [2]. HCV може викликати як гостре, так і хронічне ураження. Нові випадки інфікування HCV зазвичай перебігають безсимптомно, іноді розвивається гострий гепатит, який частіше має латентний перебіг. Близько у 30 \% інфрікованих вірус зникає спонтанно без будь-якого лікування протягом шести місяців після зараження, у решти 70 \% розвивається хронічна HCVінфрекція. У цих пацієнтів ризик розвитку цирозу печінки протягом наступних 20 років становить 15-30\%.

Україна належить до країн із середньою поширеністю гепатитів. Однак, за результатами моніторингу груп ризику щодо інсрікування HCV, захворюваність серед них значно перевищує середньосвітові показники та сягає 40-60 \%. Щорічно у країні реєструється 11-14 тис. нових випадків вірусних гепатитів. За офріційними даними Центру громадського здоров'я, на початок 2020 р. в Україні зареєстровано 7179 нових випадків HCV інсрекції, 87269 людей перебувають під медичним наглядом, протягом 2019 р. проліковано 7302 пацієнти. 
Цироз печінки, пов'язаний з гепатитом С (ГС), є наслідком тривалого пошкодження печінки вірусом. Одним 3 найважливіших фракторів для лікування фріброзу печінки є усунення основної причини хронічного пошкодження печінки. Таким чином, елімінація HCV є кардинальною умовою для регресу цирозу печінки [3]. Методи лікування, засновані на використанні противірусних препаратів прямої дії, запровадили нову еру в лікуванні ГС. Вони дозволяють викорінити вірус майже без побічних ефектів у більшості хворих на цироз, тим самим досягнувши зменшення ризику розвитку гепатоцелюлярної карциноми, декомпенсації печінки та смертності [2].

Разом з тим, на сьогодні немає чітких клінічних та епідеміологічних даних, які б дозволили здійснювати дисеренційну діагностику вірусного походження цирозу печінки.

Враховуючи актуальність проблеми, поставлено за мету дослідити клініко-лабораторні особливості цирозу печінки, асоційованого з вірусами гепатитів.

\section{Пацієнти і методи}

Проаналізовано медичні карти стаціонарних хворих та обстежено 107 пацієнтів віком $(47,1 \pm 12,1)$ року, які отримували лікування у КНП СОР «Медичний клінічний центр інфекційних хвороб та дерматології імені 3. Красовицького» та Сумській обласній клінічній лікарні у 2015-2019рр. Клінічні дані та біохімічні показники крові зіставляли з групою порівняння, яку склали 70 практично здорових осіб віком $(45,6 \pm 2,1)$ року. Пацієнтам проведено клінічний аналіз крові (Elite 3, CobasMicros), біохімічний аналіз крові (ChemWell, COBASEMira). Для розрахунку тесту APRI використовували кількість тромбоцитів та рівень аспартатамінотрансферази (АСТ), при значенні показника більше 1,0 вважали, що ймовірність значного фріброзу велика. Щоб розрахувати FIB-4, використовували такі показники: АCT, АЛТ, кількість тромбоцитів, а також вказували вік хворого. При значенні менше 1,45 ймовірність значного фріброзу мала (90 \%), при показнику 3,25 - велика.

Результати досліджень були опрацьовані методом варіаційної статистики (критерій Манна-Уїтні та $\chi^{2}$ з використанням комп'ютерних програм Microsoft Office Excel i IBM SPSS Statistic 23.

\section{Результати досліджень та їх обговорення}

Усі хворі були поділені на дві групи: у 1-у увійшло 57 пацієнтів з цирозом печінки, асоційованим з вірусами гепатитів віком $(44,3 \pm 1,36)$ року; середній показник індексу маси тіла (IMT) склав $(25,5 \pm 0,5)$, переважали чоловіки (63,2 \%). 2-у групу склали 50 пацієнтів 3 цирозом печінки невірусного походження, тут також пере- важали чоловіки $(64,0 \%)$ віком $(50,4 \pm 1,9)$ року, середній показник IMT склав $(27,1 \pm 0,82)$.

Серед обстежених 1-ї групи переважав цироз, обумовлений HCV (84,2 \%), вірусом гепатиту B; коінфекція вірусів B+D і B+C обумовлювали цироз більше ніж у 5 разів рідше (відповідно 8,8, 5,3 і 1,7 \%). У цій групі переважали мешканці міста (70,2%). Ймовірними шляхами зараження, на які вказували хворі, були медичні маніпуляції (18,5 \%); лікування у стоматолога (11,1 \%); донорство і вживання ін'єкційних наркотиків (по 7,4 \%); переливання крові або ії складників (5,5\%); професійна діяльність (медичні працівники - 1,8\%); невстановлений шлях - у 48,3 \% обстежених.

В осіб цієї групи переважала мінімальна активність (64,9 \%), у 3,4 разу рідше - помірна (19,3 \%), у 4,1 разу - виражена (15,8 \%). Декомпенсований цироз (за класифікацією Чайлд-П'ю) зареєстрований у 3,6 \% осіб, субкомпенсований - у 35,0 \%, компенсований -у 61,4 \%. Згідно з тестом APRI, 7,0 \% пацієнтів не мали фріброзу печінки, у 19,3 \% підтверджено фріброз, 73,7 \% отримали сумнівний результат. Визначенням фріброзу за допомогою показника FIB-4 було отримано значення, що вказують на відсутність цирозу у 5,3 \% обстежених, у 66,7 \% - високу ймовірність цирозу, у 28,0 \% - сумнівну вірогідність.

У 2-й групі також переважали мешканці міста (62,0 \%), ймовірний шлях зараження відсутній, переважала печінково-клітинна недостатність II ступеня $(66,0 \%)$, І ступінь ії діагностовано у 2,4 разу рідше (28,0 \%). За допомогою іншого тесту FIB-4 у 60,0 \% була сумнівна вірогідність ураження, висока ймовірність цирозу та відсутність фріброзу встановлено рівномірно по $20,0 \%$.

У 1-й групі астено-вегетативний синдром виявлений у 1,4 разу частіше, ніж у 2-й групі, тяжкість у правому підребер'ї та асцит у 1,2 і 1,1 разу відповідно, що вказує на тяжчий перебіг захворювання (табл. 1). При об'єктивному обстеженні переважали спленомегалія і субіктеричність склер відповідно в 1,3 і 3,0 разу частіше.

Енцефалопатію реєстрували у 4 рази частіше, ніж у 2-й групі, холецистит - в 1,4. У кожного третього пацієнта 1-ї групи діагностовано метаболічну кардіоміопатію. Гастроезофрагеальну рефрюксну хворобу (20 \%) виявлено серед обстежених 2-ї групи.

У 1-й групі встановлено збільшення рівня моноцитів у 1,4 разу, ШОЕ - у 2 рази; зменшення вмісту тромбоцитів у 2 рази нижче відносно групи порівняння; зменшення еритроцитів в 1,1 разу (табл. 2), що свідчить про агресивний вплив вірусу гепатиту на кровотворну систему організму. 
Особливості клінічних ознак у хворих на цироз, залежно від етіології

\begin{tabular}{|c|c|c|c|}
\hline \multirow{2}{*}{ Показник } & \multicolumn{2}{|c|}{ Група, \% } & \multirow{2}{*}{$P$} \\
\hline & $1-a(n=57)$ & $2-a(n=50)$ & \\
\hline \multicolumn{4}{|l|}{ Синдром } \\
\hline астено-вегетативний & 93,0 & 66,0 & $0,001^{*}$ \\
\hline диспептичний & 19,3 & 22,0 & 0,730 \\
\hline тяжкість у правому підребер'ї & 71,9 & 60,0 & 0,270 \\
\hline асцит & 24,5 & 22,0 & 0,198 \\
\hline \multicolumn{4}{|l|}{ Об'єктивні зміни } \\
\hline гепатомегалія & 78,9 & 86,0 & 0,656 \\
\hline спленомегалія & 47,4 & 38,0 & 0,329 \\
\hline субіктеричність склер & 42,1 & 14,0 & 0,000 * \\
\hline \multicolumn{4}{|l|}{ Супутня патологія } \\
\hline холецистит & 31,6 & 22,0 & 0,266 \\
\hline енцефралопатія & 15,8 & 4,0 & $0,000^{*}$ \\
\hline цукровий діабет & 7,0 & 8,0 & 0,847 \\
\hline
\end{tabular}

Примітка. * - достовірна різниця показника відносно 1-ї групи ( $<<0,05$, розраховано за критерієм $\left.\chi^{2}\right)$.

Таблиця 2

Особливості змін лабораторних показників у хворих на цироз, залежно від етіології

\begin{tabular}{|c|c|c|c|}
\hline \multirow{2}{*}{ Показник } & \multicolumn{3}{|c|}{ Група, Мe (Q1-Q3) } \\
\hline & порівняння $(n=60)$ & $1-a(n=57)$ & $2-a(n=50)$ \\
\hline Еритроцити, Т/л & $4,3(4,2-4,6)$ & $\begin{array}{c}3,8(3,4-4,5) \\
p_{2}=0,000^{*}\end{array}$ & $\begin{array}{c}3,2(3,0-3,5) \\
p_{1}=0,000 * ; p_{2}=0,000^{*}\end{array}$ \\
\hline Гемоглобін, г/л & $136,0(128,3-140,0)$ & $\begin{array}{c}119,0(108,0-137,0) \\
p_{2}=0,000 *\end{array}$ & $\begin{array}{l}116,0(100,0-127,5) \\
p_{1}=0,091 ; p_{2}=0,000^{*}\end{array}$ \\
\hline Тромбоцити, Г/л & $212,0(187,3-237,0)$ & $\begin{array}{c}103,0(63,8-165,8) \\
p_{2}=0,000^{\star}\end{array}$ & $\begin{array}{c}162,0(139,5-198,0) \\
p_{1}=0,000^{*} ; p_{2}=0,000^{*}\end{array}$ \\
\hline Лейкоцити, Г/л & $5,0(4,2-5,5)$ & $\begin{array}{c}4,3(2,8-6,2) \\
p_{2}=0,379\end{array}$ & $\begin{array}{c}4,7(3,7-6,8) \\
p_{1}=0,534 ; p_{2}=0,400\end{array}$ \\
\hline Моноцити, \% & $6,0(5,0-8,0)$ & $\begin{array}{c}8,5(5,3-11,0) \\
p_{2}=0,002^{*}\end{array}$ & $\begin{array}{c}9,0(7,0-12,0) \\
p_{1}=0,188 ; p_{2}=0,000^{*}\end{array}$ \\
\hline Лімфоцити, \% & $32,5(29,0-38,8)$ & $\begin{array}{c}35,0(22,8-42,8) \\
p_{2}=0,670\end{array}$ & $\begin{array}{c}24,5(20,0-32,3) \\
p_{1}=0,002 ; p_{2}=0,000^{*}\end{array}$ \\
\hline ШОЕ, мм/год & $9,0(6,0-12,0)$ & $\begin{array}{c}18,0(7,5-27,0) \\
p_{2}=0,000^{\star}\end{array}$ & $\begin{array}{c}11,0(6,0-24,5) \\
p_{1}=0,191 ; p_{2}=0,047^{*}\end{array}$ \\
\hline
\end{tabular}

Примітки (тут і далі): * - достовірна різниця показника (р<0,05, розраховано за критерієм Манна-Уїтні), p $_{1}$ - відносно 1-ї групи; $p_{2}$ - відносно контрольної. 


\section{ОРИГІНАЛЬНІ ДОСЛІДЖЕННЯ}

У 2-й групі середній показник тромбоцитів був менше у 1,3 разу відповідно до групи порівняння, але більше, ніж в 1,6 разу, ніж у 1-й групі. Гемоглобін мав найменші показники серед досліджуваних груп, що вказує на ризик виникнення анемії або прихованої крововтрати. шОЕ була в 1,6 разу меншою, ніж у І-й групі але у 1,2 разу вище від групи порівняння. Відповідно до практично здорових осіб кількість лейкоцитів і моноцитів збільшилась в 1,1 і 1,5 разу, що може свідчити про наявність запального процесу (табл. 2).

При аналізі змін біохімічних показників крові: у 1-й групі в 1,1 разу був збільшений вміст загального білка, загального білірубіну - у 2,8 разу відносно групи порівняння та у 3,6 разу відносно 2-ї групи; показник АЛТ був вище у 5 разів, ніж у групі порівняння та у 2,5 разу від- носно до 2-ї, що вказує на значніше ураження гепатоцитів (табл. 3). У 2-й групі активність АСТ у 2 разу перевищувала значення відповідно до групи порівняння та у 4 разу проти 1-ї групи. Зниження рівня креатиніну у 1,4 разу зафріксовано у 2-й групі, у 1-й показник був в 1,1 разу вище.

При ультразвуковому дослідженні органів черевної порожнини у 1-й групі: підвищення ехогенності печінки реєстрували в 1,5 рази частіше; ущільнення стінки жовчного міхура та розширення селезінкової вени - в 4,7 і 1,3 разу частіше, ніж у 2-й групі (табл. 4); ознаки портальної гіпертензії та збільшення розмірів портальної вени в 1,3 і 2,2 разу частіше реєстрували в останній, що дає змогу припустити про значніші деструктивні зміни печінки у респондентів 2-ї групи.

Таблиця 3

Особливості змін у біохімічному аналізі крові хворих на цироз, залежно від етіології

\begin{tabular}{|l|c|c|c|}
\hline \multirow{2}{*}{ Показник } & \multicolumn{3}{|c|}{ Група, Me (Q1-Q3) } \\
\cline { 2 - 4 } & порівняння $(n=70)$ & $1-\mathrm{a}(\mathrm{n}=57)$ & $2-\mathrm{a}(\mathrm{n}=50)$ \\
\hline Загальний білок, г/л & $71,0(67,8-73,9)$ & $\begin{array}{c}77,0(69,5-79,9) \\
p_{2}=0,001^{*}\end{array}$ & $\begin{array}{c}68,2(62,2-74,1) \\
p_{1}=0,000^{*} ; p_{2}=0,115\end{array}$ \\
\hline Загальний білірубін, мкмоль/л & $14,4(12,4-17,9)$ & $\begin{array}{c}25,0(17,5-48,0) \\
p_{2}=0,000^{*}\end{array}$ & $\begin{array}{c}19,85(13,8-47,8) \\
p_{1}=0,191 ; p_{2}=0,047^{*}\end{array}$ \\
\hline АлТ, Од/л & $22,7(18,6-28,3)$ & $\begin{array}{c}60,0(36,0-99,5) \\
p_{2}=0,000^{*}\end{array}$ & $\begin{array}{c}40(28,8-80,8) \\
p_{1}=0,011^{*} ; p_{2}=0,000^{*}\end{array}$ \\
\hline АСТ, Од/л & $24,4(21,2-29,6)$ & $\begin{array}{c}66,0(47,5-127,0) \\
p_{2}=0,000^{*}\end{array}$ & $\begin{array}{c}48,0(27,8-90,3) \\
p_{1}=0,005^{*} ; p_{2}=0,000^{*}\end{array}$ \\
\hline Креатинін, мкмоль/л & $87,8(77,2-101,9)$ & $\begin{array}{c}66,5(57,5-81,3) \\
p_{2}=0,000^{*}\end{array}$ & $\begin{array}{c}56,0(46,8-70,5) \\
p_{1}=0,030^{*} ; p_{2}=0,000^{*}\end{array}$ \\
\hline Глюкоза, ммоль/л & $5,2(4,6-5,7)$ & $\begin{array}{c}5,23(4,80-6,0) \\
p_{2}=0,747\end{array}$ & $\begin{array}{c}4,9(4,3-5,9) \\
p_{1}=0,172 ; p_{2}=0,163\end{array}$ \\
\hline
\end{tabular}

Таблиця 4

Особливості змін при ультразвуковому дослідженні у хворих на цироз, залежно від етіології

\begin{tabular}{|c|c|c|c|}
\hline \multirow{2}{*}{ Показник } & \multicolumn{2}{|c|}{ Група } & \multirow{2}{*}{$\mathrm{P}$} \\
\hline & $1-a(n=57)$ & $2-a(n=50)$ & \\
\hline Збільшення розмірів печінки, \% & 54,7 & 54,0 & 0,968 \\
\hline Підвищення ехогенності, \% & 78,9 & 54,0 & $0,006^{*}$ \\
\hline Збільшення розмірів портальної вени, \% & 31,6 & 70,0 & $0,001^{*}$ \\
\hline Ущільнення судин, \% & 40,4 & 44,0 & 0,843 \\
\hline Ущільнення стінки жовчного міхура, \% & 56,1 & 12,0 & $0,000^{*}$ \\
\hline Збільшення розмірів селезінки, \% & 57,9 & 44,0 & 0,151 \\
\hline Розширення селезінкової вени, \% & 77,2 & 72,0 & 0,125 \\
\hline Ознаки портальної гіпертензії, \% & 66,6 & 88,0 & $0,009^{*}$ \\
\hline
\end{tabular}

Примітка. * - достовірна різниця показника відносно 1-ї групи $\left(p<0,05\right.$, розраховано за критерієм $\left.\chi^{2}\right)$. 
Як відомо, HCV-інфеекція є однією з основних причин хронічних захворювань печінки у всьому світі, цироз кінцева стадія кожного хронічного захворювання печінки. На початку захворювання хвороба перебігає латентно і проявляється астено-вегетативним або диспептичним синдромом, пацієнти не відзначають патогномонічних ознак до маніфестації значних порушень функцій печінки [4]. У нашому дослідженні цироз печінки частіше реєстрували у чоловіків, незалежно від етіології (63,2-64,0 \%). Це збігається 3 дослідженням, проведеним у 2018 р. у військовому госпіталі Мултан, і може бути пов'язано з тим, що чоловіки у два рази частіше помирають від хронічного захворювання печінки, а у жінок частіше виявляють HCV-інфекцію на ранніх етапах, саме з цієї причини знижується ризик декомпенсованого цирозу печінки порівняно з чоловіками [5]. Середній вік пацієнтів з цирозом у нашому дослідженні становив 47,1 року. Це можна порівняти з дослідженням, проведеним Siregar G.A., Gurning М., де середній вік становив 51,5 року [6]. Однак, згідно з іншим дослідженням, вік хворих становив 56,1 року. У кількох дослідженнях було показано, що старіння підвищує ризик оріброзу печінки при HCV-іноекції [5]. У цьому досліджені спостерігався наступний розподіл респондентів (класифікація Чайлд-П'ю): 61,4 \% пацієнтів були віднесені до класу A, 35,0 \% - класу B, 3,6 \% - класу C; це значно відрізняється від іншого дослідження, проведеного в лікарні Гани (західна Асрика); частота класу А становила 8,2 \%, В - 43,5\%, C - 48,3 \%. Це може бути обумовлено етнічно-соціальними фракторами та своєчасним діагностуванням патології [7]. За опублікованими результатами дослідження, проведеного у США у 2020 р., встановлений зв'язок печінкової енцефралопатії з негативними наслідками серед пацієнтів, які мають цироз печінки. У нашому дослідженні енцефалопатія була виявлена в 1-й групі значно частіше (у кожного 6-го пацієнта), ніж у 2-й [8]. У подібних пацієнтів Бразилії були значно поширені супутні захворювання серцево- судинної системи (у 62,6 \%). У нашому досліджені переважав холецистит (22,0 - 31,6 \%), серцево-судинні захворювання реєстрували рідше (15,8 \%) [9]. Згідно 3 даними Mansour D., McPherson S., асцит внаслідок портальної гіпертензії є найпоширенішим ускладненням цирозу печінки. У 60 \% пацієнтів з цирозом останній розвивається протягом 10 років після встановлення діагнозу, у нашому дослідженні у респондентів двох груп асцит розвивався значно рідше - у 22,0-24,5 \% [10]

Враховуючи зазначене, можна зробити припущення, що цироз, асоційований з вірусами гепатитів, має тяжчий перебіг і потребує комплексного обстеження, динамічного спостереження та невідкладного лікування.

\section{Висновки}

1. Незалежно від етіології цирозу, серед обстежених переважають мешканці міста (63,6 \%), чоловіки $(66,3 \%)$ віком $(50,4 \pm 1,9)$ року, 3 надмірною масою $(27,1 \pm 0,82)$. Найчастіше ймовірним шляхом зараження при вірусному цирозі є медичні маніпуляції (5,5-18,5 \%) і вживання ін'єкційних наркотиків (по 7,4 \%). Незважаючи на переважання мінімальної активності і цирозу класу A і В (за Чайлд-П'ю) при вірусних гепатитах, неінвазивні тести вказують на більшу кількість пацієнтів з вираженим фріброзом у цій групі.

2. Астено-вегетативний синдром, тяжкість у правому підребер'ї, субіктеричність склер, спленомегалія, енцефалопатія домінують при цирозах, поєднаних 3 вірусами гепатитів, а серед супутніх захворювань - холецистит, метаболічна кардіоміопатія.

3. При цирозах, обумовлених вірусами гепатитів, спостерігається значне зниження кількості тромбоцитів та прискорення ШОЕ, підвищення вмісту загального білірубіну, АЛт при зниженні рівня креатиніну.

4. За даними ультразвукового дослідження, при вірусному ураженні печінки частіше спостерігається збільшення ехогенності печінки і розширення розміру селезінкової вени, ущільнення стінки жовчного міхура.

\section{Література}

1. Hepatic cirrhosis / J. I. Fortea, I. G. Carrera, A. Puente, J. Crespo // Medicine (Spain). - 2020. - Vol. 13 (6). - P. 297-307.

2. Conde I. Hepatitis C-related cirrhosis. Current status / I. Conde, C. Vinaixa, M. Berenguer // Medicina Clinica. - 2017. - Vol. 148 (2). - P. 78-85.

3. Liver remodeling on ct examination in patients with hcv compensated cirrhosis who achieved sustained virological response after direct-acting antivirals treatment / F. Mihai, A. Trifan, C. Stanciu [et al.] // Medicina (Lithuania). - 2020. - Vol. 56 (4).
4. Ferenci P. Are all cirrhotic patients equal? / P. Ferenci // Journal of Hepatology. - 2020. - Vol. 72 (3). - P. 389-390. DOI:10.1016/j. jhep.2019.10.022.

5. Factors associated with renal dysfunction in hepatitis C-related cirrhosis and its correlation with child-pugh score / H. W. Bhatti, U. Tahir, N. A. Chaudhary [et al.] // BMJ Open Gastroenterology. - 2019. - Vol. 6 (1). DOI:10.1136/bmjgast-2019-000286.

6. Siregar G. A. Renal dysfunction in liver cirrhosis and its correlation with Child-Pugh score and MELD score / G. A. Siregar, M. Gurning // IOP Conf. Ser. Earth Environ. - Sci2018. 
7. Duah A. Oesophageal varices in patients with liver cirrhosis attending a major tertiary hospital in Ghana / A. Duah, K. N. Nkrumah, K. Tachi // Pan African Medical Journal. - 2018. - Vol. 31.

8. Outcomes after hepatic encephalopathy in population-based cohorts of patients with cirrhosis / E. B. Tapper, D. Aberasturi, Z. Zhao [et al.] // Alimentary Pharmacology and Therapeutics. - 2020. - Vol. 51 (12). - P. 1397-1405. DOI:10.1111/apt.15749

\section{References}

1. Fortea, J.I., Carrera, I.G., Puente, A., \& Crespo, J. (2020). Hepatic cirrhosis. Medicine (Spain), 13 (6), 297-307.

2. Conde, I., Vinaixa, C., \& Berenguer, M. (2017). Hepatitis C-related cirrhosis. Current status. Medicina Clinica, 148 (2), 78-85.

3. Mihai, F., Trifan A., Stanciu C., Singeap A.M., Cucuteanu, B., Ursulescu C.L., ... Cojocariu, C. (2020). Liver remodeling on ct examination in patients with hcv compensated cirrhosis who achieved sustained virological response after direct-acting antivirals treatment. Medicina (Lithuania), 56 (4).

4. Ferenci, P. (2020). Are all cirrhotic patients equal? Journal of Hepatology, 72(3), 389-390. DOI:10.1016/j.jhep.2019.10.022.

5. Bhatti, H.W., Tahir, U., Chaudhary, N.A., Bhatti, S., Hafeez, M., \& Rizvi, Z.A. (2019). Factors associated with renal dysfunction in hepatitis C-related cirrhosis and its correlation with child-pugh score. BMJ Open Gastroenterology, 6 (1) DOI:10.1136/bmjgast-2019-000286

\section{CLINICAL AND LABORATORY FEATURES OF CIRRHOSIS OF THE LIVER ASSOCIATED WITH HEPATITIS VIRUSES}

M.D. Chemych, A.O. Horbachevskyi

Sumy State University

SUMMARY. HCV infection is one of the leading causes of chronic liver disease worldwide, cirrhosis is a dangerous complication of chronic liver disease, summarizing a number of progressive stages. Beginning of the disease is latent and manifests itself in nonspecific symptoms, up to the manifestation of significant liver dysfunction.

The aim of the work is to investigate the clinical and laboratory features of liver cirrhosis associated with hepatitis viruses.

Materials and methods. Inpatient medical records were analyzed and 107 patients aged (47.1 \pm 12.1$)$ years who
9. Strauss E. Chronic hepatitis $C$ is still a problem for the public health care system in brazil / E. Strauss // Arquivos De Gastroenterologia. - 2018. - Vol. 55 (4). - P. 321-323. DOI:10.1590/ s0004-2803.201800000-90.

10. Mansour D. Management of decompensated cirrhosis / D. Mansour, S. McPherson // Clinical Medicine, Journal of the Royal College of Physicians of London. - 2018. - Vol. 18. - P. s60-s65. DOI:10.7861/clinmedicine.18-2-s60.

6. Siregar, G.A., \& Gurning, M. (2018). Renal dysfunction in liver cirrhosis and its correlation with Child-Pugh score and MELD score. IOP Conf. Ser. Earth Environ. Sci.

7. Duah, A., Nkrumah, K.N., \& Tachi, K. (2018). Oesophageal varices in patients with liver cirrhosis attending a major tertiary hospital in Ghana. Pan African Medical Journal, 31

8. Tapper, E.B., Aberasturi, D., Zhao, Z., Hsu, C., \& Parikh, N.D. (2020). Outcomes after hepatic encephalopathy in population-based cohorts of patients with cirrhosis. Alimentary Pharmacology and Therapeutics, 51 (12), 1397-1405. DOI:10.1111/apt.15749.

9. Strauss, E. (2018). Chronic hepatitis $C$ is still a problem for the public health care system in brazil. Arquivos De Gastroenterologia, 55 (4), 321-323. DOI:10.1590/s0004-2803.201800000-90.

10. Mansour, D., \& McPherson, S. (2018). Management of decompensated cirrhosis. Clinical Medicine. Journal of the Royal College of Physicians of London, 18, s60-s65. DOI:10.7861/ clinmedicine.18-2-s60. were treated at the municipal non-commercial enterprise of Sumy Regional Council "Medical Clinical Center of Infectious Diseases and Dermatology named after Z. Y. Krasovytskyi" and Sumy Regional Clinical Hospital in 2015-2019 were examined. Patients were divided into 2 groups - cirrhosis associated with hepatitis viruses (I) and cirrhosis of non-viral origin (II). Clinical data and blood biochemical parameters were compared with a comparison group of 70 healthy individuals aged (45.6 \pm 2.1$)$ years. These studies were processed by the method of variation statistics.

Results. The viral origin of cirrhosis is dominated by middle-aged, overweight male residents of the city. Despite the predominance of minimal activity and severity of class $A$ and B cirrhosis (according to Child Pugh), noninvasive tests indicated a higher number of patients with severe fibrosis in this disease. Medical manipulations and injecting drug use are the most common routes 
of infection. Astheno-vegetative syndrome, heaviness in the right hypochondrium, subicteric sclera, splenomegaly, encephalopathy, among the concomitant diseases - cholecystitis, metabolic cardiomyopathy dominate. The disease is accompanied by severe thrombocytopenia, accelerated ESR, bilirubinemia and transferasemia, increased echogenicity of the liver and enlargement of the splenic vein.

Conclusion. Cirrhosis associated with hepatitis viruses has a more severe course, pronounced clinical and laboratory symptoms with a predominance of fibrosis, requires a comprehensive examination and constant monitoring.

Key words: HCV infection; cirrhosis; fibrotest; liver ultrasound.

\section{Відомості про авторів:}

Чемич Микола Дмитрович - доктор медичних наук, професор, Сумський державний університет, завідувач кафедри інфекційних хвороб з епідеміологією; e-mail: n.chemych@kinf.sumdu.edu.ua

ORCID ID: https://orcid.org/0000-0002-7085-5448

Горбачевський Артем Олександрович - Сумський державний університет, викладач-стажист; e-mail: a.horbachevskyi@kinf.sumdu.edu.ua

ORCID ID: https://orcid.org/0000-0001-8232-1876

\section{Information about authors:}

Chemych M. D. - MD, Professor, Sumy State University, Head of the Department of Infectious Diseases and Epidemiology; e-mail: n.chemych@kinf.sumdu.edu.ua ORCID ID: https://orcid.org/0000-0002-7085-5448 Horbachevsky A. O. - Sumy State University, trainee teacher; e-mail: a.horbachevskyi@kinf.sumdu.edu.ua ORCID ID: https://orcid.org/0000-0001-8232-1876

Конфрлікт інтересів: немає.

Authors have no conflict of interest to declare.

Отримано 15.07.2020 p. 